\title{
Ecotoxicological risk assessment due to the presence of bisphenol $A$ and caffeine in surface waters in the Sinos River Basin - Rio Grande do Sul - Brazil
}

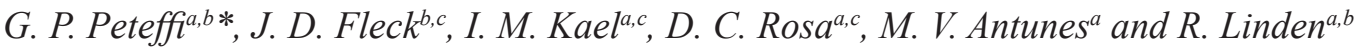 \\ ${ }^{a}$ Laboratório de Toxicologia Analítica, Pós-graduação em Toxicologia e Análises Toxicológicas, Universidade Feevale, \\ ERS 239, 2755, Vila Nova, CEP 93352-000, Novo Hamburgo, RS, Brasil \\ 'Programa de Pós-graduação em Qualidade Ambiental, Universidade Feevale, ERS 239, 2755, CEP 93352-000, \\ Novo Hamburgo, RS, Brasil \\ 'Laboratório de Microbiologia Molecular, Programa de Pós-graduação em Virologia, Universidade Feevale, ERS 239, \\ 2755, CEP 93352-000, Novo Hamburgo, RS, Brasil \\ *e-mail: gipeteffi@gmail.com
}

Received: January 3, 2018 - Accepted: March 20, 2018 - Distributed: November 30, 2019

(With 3 figures)

\begin{abstract}
Bisphenol A (BPA) is an emerging contaminant, regularly detected in aquatic ecosystems, considered as an endocrine disrupting compound (EDC). Caffeine is another chemical related to human activity, often found in surface waters. The objective of this study was to evaluate the ecotoxicological risk due to BPA and caffeine in water samples from the Sinos River basin, Rio Grande do Sul, Brazil. Water samples were collected at three sites monthly from May $9^{\text {th }}$, 2016 to April $11^{\text {th }}, 2017(\mathrm{n}=36)$. BPA concentrations in water samples collected were in the range of not detected to $517 \mathrm{ng} \mathrm{L}^{-1}$ and caffeine concentrations in the range of 41.7 to $28,439.6 \mathrm{ng} \mathrm{L}^{-1}$. The concentration of BPA in the analyzed samples had a moderate correlation with caffeine $\left(\mathrm{r}_{\mathrm{s}}=0.402\right)$. High ecotoxicological risk for BPA was characterized in $77.77 \%$ of samples, with $11.11 \%$ presenting medium and $11.1 \%$ presenting low risk. For caffeine $13.9 \%, 50 \%$ and $36.11 \%$ of the samples presented high, medium and low risk, respectively. Caffeine concentrations in water can be used as predictors of BPA concentrations above $10 \mathrm{ng} \mathrm{L}^{-1}$, the lower concentration of ecotoxicological risk, with specificity of $66.7 \%$ and sensitivity of $70.4 \%$. The assessment of aquatic risks has shown that both investigated compounds pose risks to organisms in the studied surface waters, mouth of the Pampa stream, mouth of the Luiz Rau stream and catchment point for public supply in Lomba Grande.
\end{abstract}

Keywords: endocrine disrupting, micropollutants, caffeine, bisphenol A.

\section{Risco ecotoxicológico devido à presença de bisfenol A e cafeína nas águas superficiais na Bacia do Rio Sinos - Rio Grande do Sul - Brasil}

\section{Resumo}

Bisfenol A (BPA) é um contaminante emergente regularmente detectado em ecossistemas aquáticos, é considerado um agente modificador endócrino (EDC). Além disso, outro produto químico relacionado com atividade humana, encontrado com frequência nas águas superficiais, é a cafeína. O objetivo deste estudo foi avaliar a ocorrência de risco ecotoxicológico devido a BPA e cafeína em amostras de água da Bacia Hidrográfica do Rio Sinos, Rio Grande do Sul, Brasil. Foram coletadas amostras de água em três locais mensalmente no período de 9 de maio de 2016 a 11 de abril de $2017(\mathrm{n}=36)$. As concentrações de BPA em amostras de água coletadas estavam na faixa de não detectada a $517 \mathrm{ng} \mathrm{L}^{-1} \mathrm{e}$ concentrações de cafeína na faixa de 41,7 a 28,439,6 ng L-1 A concentração de BPA nas amostras analisadas apresentou correlação moderada com a cafeína $\left(\mathrm{r}_{\mathrm{s}}=0,402\right)$. Alto risco ecotoxicológico para BPA foi caracterizado em $77,77 \%$ das amostras, com $11,11 \%$ apresentando médio e $11,1 \%$ apresentando baixo risco. Para cafeína $13,9 \%, 50 \%$ e 36,11\% das amostras apresentaram risco alto, médio e baixo, respectivamente. Concentrações de cafeína em água podem ser utilizadas como preditoras de concentrações de BPA acima de $10 \mathrm{ng} \mathrm{L}^{-1}$, menor concentração de risco ecotoxicológico, com especificidade de $66,7 \%$ e sensibilidade de $70,4 \%$. A avaliação dos riscos aquáticos revelou que ambos os compostos investigados representam risco para os organismos nas águas superficiais estudadas, foz do arroio Pampa, foz do arroio Luiz Rau e ponto de captação para abastecimento público em Lomba Grande.

Palavras-chave: modificador endócrino, micropoluentes, cafeína, bisfenol A. 


\section{Introduction}

Bisphenol A(BPA) is an emerging contaminant, regularly detected in aquatic ecosystems in trace concentrations of $n g \mathrm{~L}^{-1}$ to $\mu \mathrm{g} \mathrm{L}^{-1}$. BPA is considered an endocrine-disrupting chemical (EDC), and its presence in the aquatic environment was reported as deleterious to the reproductive systems of human and wildlife (Wu et al., 2015). Exposure to EDC, such as BPA, may lead to detrimental human health effects, including interference with both the male and female reproductive systems. This interference may cause a spectrum of disorders throughout life, including reproductive tract abnormalities and infertility, sexual precocity, hormone-related cancers and may include effects on thyroid function, obesity, and metabolism (Diamanti-Kandarakis et al., 2009). BPA is the chemical more frequently reported in surface waters, among the phenolic compounds (Zhao et al., 2009; Jonkers et al., 2010).

The primary industrial use of BPA is as a monomer for the production of epoxy resins, polycarbonates (Kang et al., 2007), phenol resins, polyesters, food cans and lacquer coatings (European Community, 2010). In Brazil, the Agência Nacional de Vigilância Sanitária (ANVISA), has imposed a ban on the sale and manufacture of plastic bottles containing BPA in January 2012 (Beserra et al., 2012). BPA has become a candidate to be included in the list of priority substances in water policy due to its environmental ubiquity, its toxicological effects and its high global production (Vom Saal et al., 2012).

In the environment, BPA is released through the natural degradation of polycarbonate plastics (Crain et al., 2007), landfill leachate via hydrolysis of BPA from plastics (Wintgens et al., 2003) and eliminated through sewage, via human-ingested BPA (Meesters and Schröder, 2002). BPA has an environmental half-life of about 4.5 days (Cousins et al., 2002), being degraded primarily by bacteria (Kang and Kondo, 2002). However, BPA did not degrade or degrade slowly under conditions of low or no oxygen (Mohapatra et al., 2010). The concentration of BPA in surface waters varies significantly according to the region and time of sampling after the discharge (Kolpin et al., 2002).

In addition to BPA, another human-related chemical frequently found is surface waters is caffeine. Caffeine has already been proposed as an anthropogenic marker for wastewater contamination of surface waters (Kurissery et al., 2012; Peeler et al., 2006), mainly because of its specific anthropic nature and high human consumption (Ferreira, 2005). Usually, caffeine is detected at relatively high concentration levels in untreated wastewater, being a ubiquitous wastewater micro-contaminant (Bueno et al., 2012). Besides being an emerging contaminant, considered a useful indicator of human contamination (Dafouz et al., 2018), caffeine is currently not included in water monitoring programs (Spence, 2015).

The ecotoxicological risk associated to the presence of a pollutant in water is considered significant, thus requiring routine monitoring, if the concentration of the compound released into the environment exceeds the ecological safety threshold, referred to as the predicted no-effect concentration (PNEC) (Wright-Walters et al., 2011). In order to evaluate the ecological risk and to provide scientific-based guidance for its management, it is necessary to determine the concentrations of these pollutants systematically and in multiple phases (Liu et al., 2016). Particularly for BPA, the European Union suggested a PNEC of $1,500 \mathrm{ng} \mathrm{L}^{-1}$ to protect aquatic organisms (European Community, 2008). Wright-Walters et al. (2011)

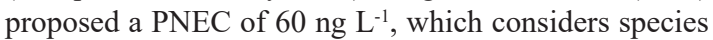
like snails, which are extremely sensitive to the effects of this chemical. Currently, the lower PNEC reported for BPA is $10 \mathrm{ng} \mathrm{L}^{-1}$, considering the effects on the larvae of the insect Chironomus riparious (Selvaraj et al., 2014). PNEC values for caffeine are much higher than for BPA, being reported as 5,200 $\mathrm{ng} \mathrm{L}^{-1}$ for the crustaceans Daphnia magna and Ceriodaphnia dubia, as well as for the algae Pseudokirchneriella subcapitata (Komori et al., 2013).

Significant ecotoxicological risks due to the presence of BPA in aquatic environment were reported previously in several locations of the World. Usually, aquatic organisms (planktons, microorganisms, plants, vertebrates, invertebrates) are affected by endocrine-disruptive toxic effects by BPA (Kang et al., 2007). Selvaraj et al. (2014) evaluated potential toxicities of BPA in three southern Indian rivers,. with BPA concentrations ranging from 2.8 to $136 \mathrm{ng} \mathrm{L}^{-1}$. Guo et al. (2015) assessed the ecological risk in surface waters of China using the risk quotient methodology, with identification of high risk for aquatic species resident in China in $42 \%$ of the studied areas. BPA ecotoxicological risk was also evaluated in receiving waters in the United States, both upstream and downstream of manufacturers and processors of BPA, with all PEC/PNEC ratios lower than one using all measured surface water concentrations of BPA, not representing an environmental concern (Staples et al., 2000).

For caffeine, water concentrations at possible risk levels were detected at Japan and Portugal (Komori et al., 2013; Paíga and Delerue-Matos, 2017). Komori et al. (2013) used the same species of our study to calculate the ecotoxicological risk, finding a risk factor of 0.46 needing more research survey. Paíga and Delerue-Matos (2017) assessed the risk at three different trophic levels (daphnia, algae, and fish). In this study, caffeine presented possible toxic effect on algae and did not pose toxicity risks to fish or daphnids. In Brazil, ecotoxicological risk assessments for these chemical have not been reported to date.

The Sinos River Hydrographic Basin (SRHB) is located in the eastern region of the state of Rio Grande do Sul, Brazil, covering 32 cities with different economic activities along its 190-km extension. The activities are distributed according to the sections of the SRHB. The upper and middle section comprise tourism, furniture, lodging and shopping industries; in the middle and lower part, the main activities comprise footwear and leather industry. The main activities at the lower section of SRHB comprises mechanical metal, food and petrochemical industries. 
Particularly, the largest industrial base of the state is located at the lower section, with significant anthropogenic influence (Figueiredo et al., 2010). The population of the Basin is estimated as 975,000 inhabitants, with $90.6 \%$ living in urban areas (FEPAM, 2016). According to Rodrigues et al. (2015), only $4.5 \%$ of the sewage from SRHB is treated, resulting in degraded water quality, mainly in its lower portion (FEPAM, 2016).

Even considering that chemical analyzes alone do not portray the environmental impact caused by the pollutants, ecotoxicological studies using the risk quotient approach are widely used worldwide as a strategy to screen for priority environmental chemical risks. Considering the lack of previous reports of ecotoxicological risk assessments of the presence of BPA and caffeine in SRHB, this study presents the first report assessing the risk of certain sentinel species exposed to BPA and caffeine in SRHB. Additionally, as caffeine is an indicator of significant contamination, we also evaluated caffeine concentrations in water as a predictor of the presence of BPA.

\section{Methods}

\subsection{Sampling sites}

Samples were collected at three points located in the lower section of SRHB (Figure 1). The Luiz Rau stream is located in the lower portion of the SRHB and due to its high extension of $13 \mathrm{~km}$, is characterized by a large concentration of urban population, receiving domestic and industrial wastewater (Ávila, 2011). The Pampa stream, approximately $9 \mathrm{~km}$ long, passes through highly populated districts, being a receiving body of industrial effluents and domestic sewage (Nascimento and Naime, 2009). Both Luiz Rau and Pampa are tributaries to the Sinos River. The third collection site was the catchment point of the water treatment plant of the city of Novo Hamburgo in the Sinos River. The sampled areas had diversified industrial production and are under anthropic pressure due to the growth of industrial park and present significant pollution of water from domestic and industrial sewage without treatment, which represents a significant threat to freshwater and coastal ecosystems (Blume et al., 2010).

\subsection{Collection of water samples}

Two liters of water samples were collected aseptically from each point in sterilized glass bottles, directly from the surface of the water stream. Collected samples were transported and maintained at refrigeration $\left(4{ }^{\circ} \mathrm{C}\right)$ until analysis. Samples from Points 1 to 3 were collected monthly for 12 months (May 2016 to April 2017). Each collection point had its location demarcated and its coordinates annotated, where P1 is S $29^{\circ} 43^{\prime} 53^{\prime \prime} / \mathrm{W} 51^{\circ} 05^{\prime} 04^{\prime \prime}$, P2 S $29^{\circ} 43^{\prime} 15^{\prime \prime} / \mathrm{W} 51^{\circ} 07^{\prime} 52^{\prime \prime}$ and P3 S $29^{\circ} 42^{\prime} 4^{\prime \prime} / \mathrm{W} 51^{\circ} 05^{\prime} 13^{\prime \prime}$.

\subsection{Meteorological data collection}

Temperature and rainfall data were obtained from the weather station of São Leopoldo (Rio Grande do Sul, Brazil) with coordinates 2946'55.2”S 5108'56.4”W (The Weather Company LLC, 2017). Collected data was from days $0,1,2$ and 7, according to the date of water sample collection.

\subsection{Caffeine determination in water}

The method for caffeine determination in water was based on Linden et al. (2015). Samples were centrifugated at $2.500 \mathrm{rpm} 10 \mathrm{~min}$ and filtered with glass fiber microfilter $(47 \mathrm{~mm})$. Aliquots of $500 \mathrm{~mL}$ of filtered water were transferred to separatory funnels, followed by $\mathrm{pH}$ adjustment to 9.0, and extracted with three portions of $25 \mathrm{~mL}$ dichloromethane. The organic extracts were added and concentrated to dryness. The dried extract was recovered

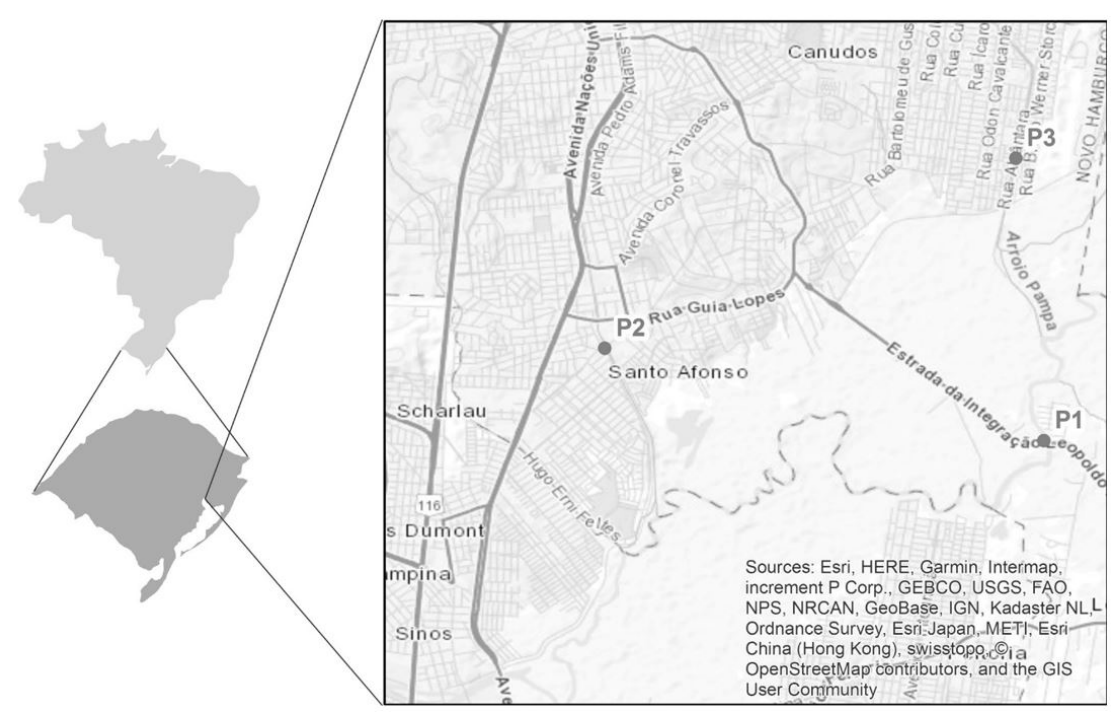

Figure 1. Geographical location of the three water points, situating in SRHB, in Rio Grande do Sul - Brazil - (P1) Catchment point for water treatment; (P2) Mouth of Luiz Rau stream; (P3) Mouth of Pampa stream. 
with $500 \mu \mathrm{L}$ of chromatographic mobile phase, and $50 \mu \mathrm{L}$ was injected in a high-performance liquid chromatography system (HPLC). Samples were analyzed using an Accela HPLC equipment, equipped with a diode array detector (Thermo Scientific). The separation was performed on a Lichrospher RP-8 column $(250 \times 4.0 \mathrm{~mm}$, p.d. $5 \mu \mathrm{m})$, obtained from Merck (Darmstadt, Germany). The mobile phase consisted of a mixture of phosphate buffer $\mathrm{pH} 2.3(50 \mathrm{mM})$ and acetonitrile $(90: 10, \mathrm{v} / \mathrm{v})$, eluted at a flow rate of $1 \mathrm{~mL} \mathrm{~min}^{-1}$. Chromatograms were monitored at $272 \mathrm{~nm}$. Retention time was $10.4 \mathrm{~min}$ for caffeine and total analytical run time was $12 \mathrm{~min}$. The method was linear from 125 to $5,000 \mathrm{ng} \mathrm{L}^{-1}$. Intra-assay precision for caffeine was in the range of $2.3-6.1 \%$, whereas inter-assay precision ranged between $2.5-4.3 \%$. Accuracy was in the range of $98.3-102.7 \%$ for caffeine.

\subsection{Bisphenol A determination in water}

BPA concentrations were measured by gas chromatography coupled to mass spectrometry (GC-MS). Water samples were centrifuged at 2,500 rpm for $10 \mathrm{~min}$ followed by a sequential filtration with glass fiber and cellulose membranes ( $47 \mathrm{~mm}, 0.45$-micron pore size). One-liter sample was $\mathrm{pH}$ adjusted to 3.0 and submitted to solid-phase extraction (SPE) with an OASIS HLB cartridge ( $3 \mathrm{~mL}, 60 \mathrm{mg}$ ). The cartridges were sequentially conditioned with $3 \mathrm{~mL}$ of tert-butyl methyl ether, $3 \mathrm{~mL}$ methanol and $3 \mathrm{~mL}$ ultrapure water in a vacuum manifold. The water sample was passed through the cartridge at a flow rate of $5 \mathrm{~mL} \mathrm{~min}{ }^{-1}$. After sample application, the cartridges were washed sequentially with $3 \mathrm{~mL}$ methanol:ultrapure water (40:60, v/v), $3 \mathrm{~mL}$ ultrapure water, $3 \mathrm{~mL}$ methanol:ultrapure water with $2 \% \mathrm{NH}_{4} \mathrm{OH}(10: 90, \mathrm{v} / \mathrm{v})$. After drying, BPA was eluted with $6 \mathrm{~mL}$ of methanol:tert-butyl methyl ether $(10: 90, \mathrm{v} / \mathrm{v})$ and spiked with $50 \mathrm{ng}$ of internal standard (IS) $\beta$-estradiol $\mathrm{D}_{5}$. Finally, the extract was dried at $60{ }^{\circ} \mathrm{C}$ and then derivatized with $13 \mu \mathrm{L}$ of piridine e $38 \mu \mathrm{L}$ of BSTFA (bis (trimethylsilyl) trifluoro-acetamide) + TMCS 99:1 at $80^{\circ} \mathrm{C}$ for $60 \mathrm{~min}$. Analyses were conducted using a Focus gas chromatograph coupled to a Thermo ISQ single-quadrupole gas chromatograph (GC/MS) system, from Thermo Scientific (San Jose, USA). Split-less injection mode was used, with injector temperature of $260{ }^{\circ} \mathrm{C}$. Chromatographic separation was performed in a $30 \mathrm{~m}$ DB-5 MS column (Agilent, USA), with $0.25 \mathrm{~mm}$ internal diameter and $0.25 \mathrm{~mm}$ thick internal coating, at

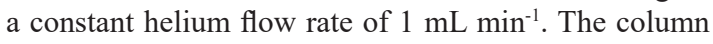
temperature program was: $70{ }^{\circ} \mathrm{C}$ for $1 \mathrm{~min}$, followed by an increase of $10{ }^{\circ} \mathrm{C} \mathrm{min}-1$ up to $200{ }^{\circ} \mathrm{C}$, hold for $1 \mathrm{~min}$, followed by another ramp of $12{ }^{\circ} \mathrm{C} \min ^{-1}$ until $260{ }^{\circ} \mathrm{C}$, with a new hold of $3 \mathrm{~min}$, then a final ramp of $15^{\circ} \mathrm{C}$ min $^{-1}$ until $310^{\circ} \mathrm{C}$, which was held for additional $5 \mathrm{~min}$. The total chromatographic analysis run time was $31.5 \mathrm{~min}$. The transfer line temperature was $250{ }^{\circ} \mathrm{C}$ and the ion source temperature was $200{ }^{\circ} \mathrm{C}$. The ions monitored for BPA were 357 (quantifying ion), 372 and 207 (qualifying ions). The ions monitored for the IS ( $\beta$-estradiol $\mathrm{D}_{5}$ ) were 421 (quantifying ion), 355 and 281 (qualifying ions). Calibration curves were calculated relating the area ratios from BPA to $\beta$-estradiol $D_{5}$ (IS). The assay was validated according to current guidelines. The assay is linear in the range of 3.5 to $400 \mathrm{ng} \mathrm{L}^{-1}$. The limit of detection of the assay was $1.2 \mathrm{ng} \mathrm{L}^{-1}$. Inter-assay precision of the assay was 7.0 to $9.4 \%$, intra-assay precision was 5.9 to $8.1 \%$ and accuracy was in the range of 94.3 to $102.1 \%$.

\subsection{Ecotoxicological risk estimation}

The ecotoxicological risk was estimated base on the ratio between the measured environmental concentration of the chemical (MEC) and the predicted no-effect concentration (PNEC), which is usually derived from toxicity tests (Wright-Walters et al., 2011). This ratio is denominated risk quotient (RQ). The PNEC for caffeine was calculated from the values of the no-effect concentration (NOEC), which had been obtained from studies using the crustaceans Daphnia magna and Ceriodaphnia dubia and the algae Pseudokirchneriella subcapitata (Komori et al., 2013) and was established as 5,200 $\mathrm{ng} \mathrm{L}^{-1}$ (Komori et al., 2013). For BPA, the lowest reported PNEC is $10 \mathrm{ng} \mathrm{L}^{-1}$, for the larvae of the insect Chironomus riparius (Selvaraj et al., 2014). Different risk levels are determined by the resulting RQ values (minimal risk: less than 0.1 , median risk: $0.1 \leq \mathrm{RQ}<1$, and high risk $\geq 1$ ) (Zhao et al., 2010). However, Komori et al. (2013) used the following criteria of ecological risk: lower than 0.1 is "acceptable"; between 0.1 and 1 "needs further survey" and equal to or higher than 1, "needs detailed evaluation."

The approach used in this study is based on an estimate of the incidence of adverse effects that occur in the water exposure at the measured concentrations. The environmental effects were characterized by the calculation of the PNEC, based on average $\mathrm{EC}_{50}$ or no observed effect concentration (NOEC) values obtained from a set of toxicity test data (EMEA, 2006). A chronic endpoint evaluation factor were used, at the order of 100 for caffeine (Komori et al., 2013) and 10 for BPA (Selvaraj et al., 2014), due to the extrapolation from intra and interspecies variability in sensitivity to the effects of the chemicals (EMEA, 2006).

\subsection{Statistical analyses}

Initially a descriptive analysis was conducted for all variables. Normality was assessed using the Shapiro-Wilk test and parametric or nonparametric statistics chosen as appropriate. Spearman correlation were used to test for associations between variables. Kruskal-Wallis test was used for the variables caffeine, BPA concentration and temperature during the seasons. Frequency of RQ ranking (minimal, median and high) were compared with all locations with the chi-square test. For all analyses $p<0.05$ was considered statistically significant. In addition, receiver operating characteristic (ROC) curves were set to determine a concentration threshold for caffeine as a predictor of the presence of BPA in surface waters, at different sensitivity and specificity levels. Statistical analyses were performed with SPSS version 22 (IBM, USA).

\section{Results}

BPA and caffeine measured concentrations are presented in Table 1. BPA concentrations in water samples collected in P1, P2 and P3 were in the range of not detected to $274.2 \mathrm{ng} \mathrm{L}^{-1}$, not detected to $498.2 \mathrm{ng} \mathrm{L}^{-1}$ and 
Table 1. Caffeine and BPA levels, risk quotients (RQ) and ecotoxicological risk classification in the evaluated water collection sites.

\begin{tabular}{|c|c|c|c|c|c|c|c|}
\hline $\begin{array}{c}\text { Collection } \\
\text { date }\end{array}$ & $\begin{array}{l}\text { Collection } \\
\text { site }\end{array}$ & $\begin{array}{c}\text { BPA } \\
\left(n g L^{-1}\right)\end{array}$ & $\begin{array}{l}\text { caffeine } \\
\left(n g L^{-1}\right)\end{array}$ & $\begin{array}{c}\text { MEC/ } \\
\text { PNEC } \\
\text { BPA }\end{array}$ & $\begin{array}{c}\text { MEC/ } \\
\text { PNEC } \\
\text { caffeine }\end{array}$ & $\begin{array}{c}\text { RQ } \\
\text { BPA }\end{array}$ & $\begin{array}{c}\text { RQ } \\
\text { caffeine }\end{array}$ \\
\hline \multicolumn{8}{|l|}{ May $9^{\text {th }}, 2016$} \\
\hline & $\mathrm{P} 1$ & 94.2 & 465.5 & 9.42 & 0.09 & High & Minimal \\
\hline & $\mathrm{P} 2$ & 31.7 & $3,896.2$ & 3.17 & 0.75 & High & Median \\
\hline & P3 & 260.5 & $5,503.4$ & 26.05 & 1.06 & High & High \\
\hline \multicolumn{8}{|l|}{ June $6^{\text {th }}, 2016$} \\
\hline & $\mathrm{P} 1$ & 67.4 & 236.6 & 6.74 & 0.05 & High & Minimal \\
\hline & $\mathrm{P} 2$ & ND & $1,221.9$ & 0 & 0.23 & Minimal & Median \\
\hline & P3 & 40.4 & $1,533.3$ & 4.04 & 0.29 & High & Median \\
\hline \multicolumn{8}{|l|}{ July $5^{\text {th }}, 2016$} \\
\hline & $\mathrm{P} 1$ & 13.4 & 168.3 & 1.34 & 0.03 & High & Minimal \\
\hline & $\mathrm{P} 2$ & 48.4 & $4,509.3$ & 4.84 & 0.87 & High & Median \\
\hline & P3 & 137.0 & $1,251.2$ & 13.70 & 0.24 & High & Median \\
\hline \multicolumn{8}{|c|}{ August $8^{\text {th }}, 2016$} \\
\hline & $\mathrm{P} 1$ & 77.3 & $24,619.8$ & 7.73 & 4.73 & High & High \\
\hline & $\mathrm{P} 2$ & 498.2 & $4,893.7$ & 49.82 & 0.94 & High & Median \\
\hline & P3 & 101.7 & $1,508.4$ & 10.17 & 0.29 & High & Median \\
\hline \multicolumn{8}{|c|}{ September $12^{\text {th }}, 2016$} \\
\hline & $\mathrm{P} 1$ & 11.9 & 41.7 & 1.19 & 0.01 & High & Minimal \\
\hline & $\mathrm{P} 2$ & 28.9 & 829.6 & 2.89 & 0.16 & High & Median \\
\hline & P3 & 216.6 & $2,154.4$ & 21.66 & 0.41 & High & Median \\
\hline \multicolumn{8}{|c|}{ October $3^{\text {th }}, 2016$} \\
\hline & $\mathrm{P} 1$ & ND & 138.4 & 0 & 0.03 & Minimal & Minimal \\
\hline & $\mathrm{P} 2$ & ND & $7,497.1$ & 0 & 1.44 & Minimal & High \\
\hline & P3 & 237.1 & $4,877.3$ & 23.71 & 0.94 & High & Median \\
\hline \multicolumn{8}{|c|}{ November $7^{\text {th }}, 2016$} \\
\hline & $\mathrm{P} 1$ & 274.2 & 140.0 & 27.42 & 0.03 & High & Minimal \\
\hline & P2 & 177.2 & 526.2 & 17.72 & 0.10 & High & Median \\
\hline & P3 & 338.2 & $2,235.1$ & 33.82 & 0.43 & High & Median \\
\hline \multicolumn{8}{|c|}{ December $5^{\text {th }}, 2016$} \\
\hline & $\mathrm{P} 1$ & 12.0 & 41.7 & 1.20 & 0.01 & High & Minimal \\
\hline & $\mathrm{P} 2$ & 83.3 & $28,439.6$ & 8.33 & 5.47 & High & High \\
\hline & P3 & 79.5 & $1,413.3$ & 7.95 & 0.27 & High & Median \\
\hline \multicolumn{8}{|c|}{ January $9^{\text {th }}, 2017$} \\
\hline & $\mathrm{P} 1$ & 3.5 & 267.5 & 0.35 & 0.05 & Median & Minimal \\
\hline & $\mathrm{P} 2$ & 100.1 & 197.2 & 10.01 & 0.04 & High & Minimal \\
\hline & P3 & 517.0 & 328.5 & 51.70 & 0.06 & High & Minimal \\
\hline \multicolumn{8}{|c|}{ February $21^{\text {th }}, 2017$} \\
\hline & $\mathrm{P} 1$ & ND & 41.7 & 0 & 0.01 & Minimal & Minimal \\
\hline & $\mathrm{P} 2$ & 145.0 & $3,186.7$ & 14.50 & 0.61 & High & Median \\
\hline & P3 & 15.0 & $1,720.8$ & 1.50 & 0.33 & High & Median \\
\hline \multicolumn{8}{|c|}{ March $6^{\text {th }}, 2017$} \\
\hline & $\mathrm{P} 1$ & 4.5 & 41.7 & 0.45 & 0.01 & Median & Minimal \\
\hline & $\mathrm{P} 2$ & 211.3 & $2,352.3$ & 21.13 & 0.45 & High & Median \\
\hline & P3 & 3.7 & $2,077.0$ & 0.37 & 0.40 & Median & Median \\
\hline \multicolumn{8}{|c|}{ April $11^{\text {th }}, 2017$} \\
\hline & $\mathrm{P} 1$ & 7.1 & 127.8 & 0.71 & 0.02 & Median & Minimal \\
\hline & $\mathrm{P} 2$ & 142.5 & $24,451.9$ & 14.25 & 4.70 & High & High \\
\hline & P3 & 40.4 & 783.2 & 4.04 & 0.15 & High & Median \\
\hline
\end{tabular}

$\mathrm{ND}=$ not detected; PNEC caffeine $=5,200 \mathrm{ng} \mathrm{L}$ L $^{-1}$ (Komori et al., 2013); PNEC BPA $10 \mathrm{ng} \mathrm{L}^{-1}$ (Selvaraj et al., 2014); RQ = risk quotient. 

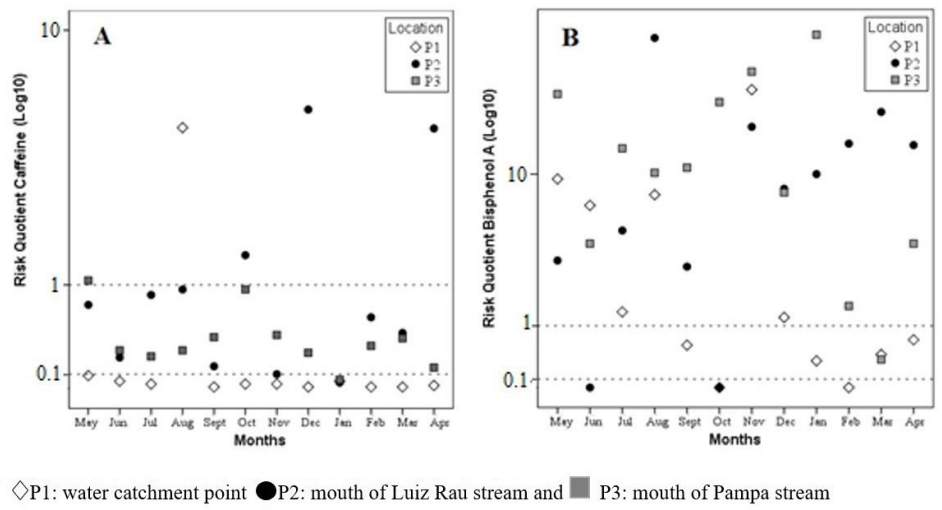

Figure 2. (A) Risk quotient of caffeine for one year at the three collection sites; (B) Risk quotient of BPA for one year at the three collection sites. May $9^{\text {th }}, 2016$ to April $11^{\text {th }}, 2017$.

3.7 to $517 \mathrm{ng} \mathrm{L}^{-1}$, respectively. Caffeine concentrations in the sample collection points were in the range of 41.7 to $24,619.8,197.2$ to $28,439.6$ and 328.5 to $5,503.4 \mathrm{ng} \mathrm{L}^{-1}$ for P1, P2 and P3. There was a moderate Spearman correlation between caffeine and BPA concentrations, considering all points $\left(\mathrm{r}_{\mathrm{s}}=0.402, \mathrm{p}=0.015, \mathrm{n}=36\right)$.

There was no statistical difference in BPA concentrations among the three water collection points ( $\mathrm{p}=0.097$, Kruskal-Wallis). P1 had median BPA concentration of $9.53 \mathrm{ng} \mathrm{L}^{-1}$ (Q1 $3.99 \mathrm{ng} \mathrm{L}^{-1}$, Q3 72.35 $\left.\mathrm{ng} \mathrm{L}^{-1}\right)$, P2 had median BPA concentration median of $91.71 \mathrm{ng} \mathrm{L}^{-1}$ (Q1 $30.32 \mathrm{ng} \mathrm{L}^{-1}$, Q3 $161.11 \mathrm{ng} \mathrm{L}^{-1}$ ) and P3 had median BPA levels of $104.99 \mathrm{ng} \mathrm{L}^{-1}$ (Q1 $40.4 \mathrm{ng}$ $\mathrm{L}^{-1}$, Q3 $\left.248.81 \mathrm{ng} \mathrm{L}^{-1}\right)$. However, there was a statistical difference among the three points when comparing caffeine concentrations ( $p=0.02$, Kruskal-Wallis), with P2 and P3 not differing according to Mann-Whitney test ( $p=0.266$ ). The concentration of caffeine in $\mathrm{P} 1$ is statistically different from P2 ( $<<0.001$, Mann-Whitney test) and P3 ( $<<0.001$, Mann-Whitney test). P1 had median caffeine concentration of $139.20 \mathrm{ng} \mathrm{L}^{-1}$ (Q1 $41.67 \mathrm{ng} \mathrm{L}^{-1}$, Q3 252.07 $\mathrm{ng} \mathrm{L}^{-1}$ ), P2 had median caffeine levels of $3541.41 \mathrm{ng} \mathrm{L}^{-1}$ (Q1 $1025.72 \mathrm{ng} \mathrm{L}^{-1}$, Q3 6195.38 $\mathrm{ng} \mathrm{L}^{-1}$ ) and P3 had median caffeine concentrations of 1332.24 ng L-1 (Q1 1332.24, Q3 2194.76 ng L-1).

The ecotoxicological risk was estimated considering the RQ. BPA presented a maximum RQ value of 51.7, in P3. Considering the 36 measured concentrations, $77.77 \%$ (28) of all measured BPA levels presented high risk, while $11.11 \%$ (4) presented medium and $11.1 \%$ (4) presented low risk. There was no statistical difference between the frequency of BPA risk among the three sampled points ( $\mathrm{p}=0.068$, Chi-square test). For caffeine, the maximum RQ was in P2, of 5.47, and $13.9 \%$ (5) of all measured levels presented high risk, while $50 \%$ (18) presented medium and $36.11 \%$ (11) presented low risk. However, there was a statistical difference between the frequency of caffeine risk among the three collection points ( $\mathrm{p}=<0.001$, Chi-square test) (Figure 2). Caffeine was detected in all collected samples, from the three different locations.

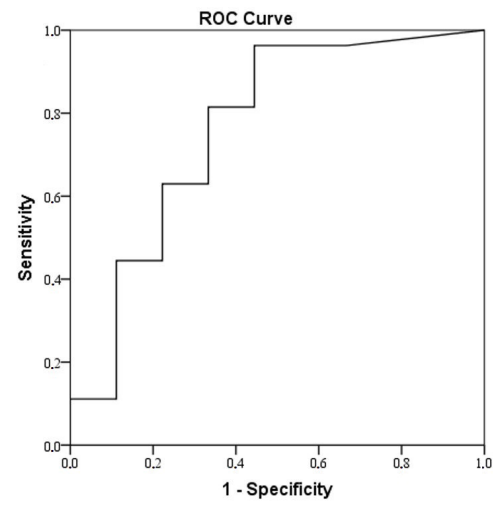

Figure 3. Receiver operating characteristics (ROC) curves of caffeine to identify the presence of BPA above $10 \mathrm{ng} \mathrm{L}^{-1}$ (PNEC).

Temperature was significantly higher in summer (median $27^{\circ} \mathrm{C}, \mathrm{p}=0.002$, Kruskal Wallis), than in winter (median $19.2^{\circ} \mathrm{C}$ ). As there was no correlation between rainfall and $R Q$, probably the flow of the streams did not influence the measurements. The RQ were also not influenced by temperature.

The capability of caffeine to predict whether the surface water sample has BPA concentrations about the PNEC was evaluated by ROC curves (Figure 3). The ROC curve for caffeine had an area under the curve (AUC) of $0.763(95 \%$ CI of 0.0558 to $0.969, p=0.019)$. The agreement between identification of possible presence of BPA using the quantification of caffeine was satisfactory.

Sensitivity and specificity of caffeine tests to identify BPA was set using the cut-off selected after the ROC analysis. Using the best cut off for caffeine concentrations was $654.7 \mathrm{ng} \mathrm{L}^{-1}$, which has $70.4 \%$ sensitivity and $66.7 \%$ specificity to identify the presence BPA in concentrations above $10 \mathrm{ng} \mathrm{L}^{-1}$, a level correspondent to the currently lower available PNEC. Setting a higher threshold value for caffeine, of 1,332.24 $\mathrm{ng} \mathrm{L}^{-1}$, leads to an increase in specificity $(77.8 \%)$, but at a lower sensitivity of $59.3 \%$. 


\section{Discussion}

BPA is the most frequently detected chemical in aquatic environment around the world (Fromme et al., 2002; Jin and Zhu, 2016; Kolpin et al., 2002; Yamazaki et al., 2015) among the phenolic compounds (Zhao et al., 2009; Jonkers et al., 2010). In our study, BPA was found at concentrations from not detected to $517.03 \mathrm{ng} \mathrm{L}^{-1}$, in line with BPA levels in the aquatic environment reported in the literature, in the range from $0.0005 \mu \mathrm{g} \mathrm{L}^{-1}$ to $8 \mu \mathrm{g} \mathrm{L}^{-1}$ (Wright-Walters et al., 2011). In Rio das Velhas (Brazil) the BPA concentration ranged from 8.6 to $168.3 \mathrm{ng} \mathrm{L}^{-1}$ (Moreira et al., 2011). In surface water samples from Iguassu River, in the metropolitan region of Curitiba (Brazil), BPA had concentrations between $0.62 \pm 0.15$ and $12.61 \pm 0.21 \mu \mathrm{g} \mathrm{L}^{-1}$ (Froehner et al., 2011).

Water samples vary greatly in their concentration of BPA, depending on location and time of sampling. River waters from the United States presented BPA concentrations between non-detectable and $12 \mu \mathrm{g} \mathrm{L}^{-1}$ (Kolpin et al., 2002). In Poland, BPA levels between 5 and $95 \mathrm{ng} \mathrm{L}^{-1}$ were found (Czarczynska-Góslinska et al., 2017), where in China the concentrations levels were 27.95 to $565.40 \mathrm{ng} \mathrm{L}^{-1}$ (Liu et al., 2016). Very high values were found in Portugal, ranging from 0.07 to $4.0 \mu \mathrm{g} \mathrm{L}^{-1}$ (Azevedo et al., 2001). The main compartment where BPA is found is the aquatic, due to the partition coefficient $\log$ octanol-water $\left(\log \mathrm{K}_{\text {ow }}\right)$ of 3.32 . Because of this characteristic, an appreciable fraction remains in the dissolved phase (Klečka et al., 2009) and the rate of evaporation from soil and water is low (Groshart et al., 2001). BPA is a moderately hydrophobic chemical, degraded mostly in aerobic conditions. BPA is expected to have low bioaccumulation and low persistence, but it has been detected in the environment commonly mainly due to its continuous release (Groshart et al., 2001).

Even considering that collection points had no significant differences in BPA concentrations between collection points $\mathrm{P} 2$ and $\mathrm{P} 3$, there is a tendency for lower levels in P1, a rural area. Corroborating to other studies, the distribution pattern indicates that the major source of BPA is the industrial sector (Fürhacker et al., 2000; Guo et al., 2015). However, a contribution from domestic effluents is also likely, due to the moderate correlation of BPA levels with caffeine concentrations. Human exposure occurs continuously at low doses through contact with beverage containers, food can coatings, in addition to occupational exposure (Health Canada, 2008). BPA is rapidly metabolized by humans and excreted in urine, with elimination within $24 \mathrm{~h}$ after exposure (Teeguarden et al., 2011). Caffeine has already been proposed as an anthropogenic marker for wastewater contamination of surface waters (Kurissery et al., 2012). For caffeine, the highest concentrations, most of the time, were found in streams that pass through highly populated districts with P1 being the site with the higher frequency (91.7\%) of high risk (Figure 2, $n=12, p=0.00$, Chi-square test).The quantification of BPA in the tested samples from SRHB presented moderate correlation with caffeine $\left(r_{s}=0.402\right)$. Montagner et al. (2014) showed the direct univariate correlation between caffeine concentration and estrogenic activity, evaluated by the bioluminescent yeast estrogen receptor assay (BLYES). These authors found a correlation coefficient of $r=0.4664$ between caffeine concentration and estrogenic activity, which is similar of our results when comparing BPA and caffeine water concentrations. Montagner et al. (2014) concluded that water caffeine concentrations can be used to prioritize samples to be tested for estrogenic activity in water quality programs, evaluating emerging contaminants with endocrine disruptor activity, like BPA. Based in our preliminary results, a similar approach can be used, using caffeine concentrations to select samples eligible for a more complex BPA measurement. Furthermore, using caffeine as a predictive indicator of estrogenicity, it is possible to identify which months must receive more attention regarding endocrine modifying activity.

As caffeine concentrations in water are considered a good indicator of the presence of sewage from human origin, we explored the use of caffeine concentrations as a possible indicator of the presence of BPA above the PNEC of $10 \mathrm{ng} \mathrm{L}^{-1}$. A caffeine concentration of $654.7 \mathrm{ng} \mathrm{L}^{-1}$ presented $70.4 \%$ sensitivity (about $30 \%$ of false negatives) and $66.7 \%$ specificity (about $33 \%$ of false positives) to identify the presence of BPA in concentrations above $10 \mathrm{ng} \mathrm{L}^{-1}$. This finding warrants further research in the evaluation of caffeine as an indicator of the significant presence of EDC, as already proposed by Montagner et al. (2014). Caffeine concentrations were correlated to BPA and could potentially be used as a chemical indicator of the level of contamination by sanitary sources. This finding is particularly interesting when considering that caffeine measurement if much simpler than the determination of BPA in water, which usually requires the use of mass spectrometry.

In this study, PNEC values for Chironomus riparious and cladocerans were employed for the evaluation of BPA ecotoxicological risk and PNEC values from algae were used to evaluate caffeine ecotoxicological risk. These species occupy different trophic positions in the aquatic ecosystem and, due to a lack of data on the PNEC of native species, evalauted a scenario using alternative species, also protecting upper trophic levels. In the Brazilian study of Spadoto (2013), which used native species, BPA in concentrations higher than those found in the environment caused acute toxicity to Daphnia similis and Ceriodaphnia silvestrii, with median $\mathrm{CE}(\mathrm{I})_{50}$ of $10.64 \mathrm{mg} \mathrm{L}^{-1}( \pm 2.008)$ and $19.9 \mathrm{mg} \mathrm{L}^{-1}( \pm 10.71)$ respectively. Ceriodaphnia silvestrii and Chironomus xanthus presented chronic sensitivity to BPA at concentrations higher than those found in the environment (Moreira, 2010; Beraldo, 2012).

The measured environmental concentrations of BPA and caffeine in the evaluated streams of the SRHB were used to assess the ecotoxicological risk by a hazard quotient approach. Considering the highest values of MECs, no evaluated species is protected, probably the sources of pollution differ. The concentrations of caffeine in $\mathrm{P} 1$ is significantly lower than P2 and P3 because the flow in 
the Sinos River (P1) is much higher than in the streams, belonging to a rural area, In the other hand, P2 and P3 cross the urban area of the city of Novo Hamburgo, with industrial and domestic sewage interferences. There was no statistical difference between the collection points regarding BPA concentration, but a tendency of increasing concentrations from P1 to P3. This pattern of BPA distribution indicates that the main source of origin is the industrial sector (Guo et al., 2015).

\section{Conclusion}

This study is the first report of the evaluation of ecotoxicological risk posed to chemicals in the Sinos River Hydrographic Basin using the risk quotient approach. High ecotoxicological risk was identified in water catchment point, mouth of Luiz Rau stream and mouth of Pampa stream due to the presence of the endocrine disruptor chemical bisphenol A and to caffeine. Caffeine concentrations were moderately correlated to bisphenol A levels. Caffeine concentrations can be used to screen water samples with bisphenol A concentrations at risk levels, with reasonable sensitivity. Additional studies on the effects of these pharmaceuticals on other aquatic organisms and its presence on water sources are necessary for further evaluation and possible future measures.

\section{Acknowledgements}

This study was funded by a grant from the Conselho Nacional de Desenvolvimento Científico e Tecnológico (CNPq) - 454066/2014-7. R Linden is recipient of a research scholarship from CNPq.

\section{References}

ÁVILA, C.L.A., 2011. Preliminar de metais pesados totais e biodisponiveis em profundidade no sedimento do arroio Luiz Rau em Novo Hamburgo (RS). Novo Hamburgo: Universidade Feevale, 74 p. Trabalho de Conclusão de Curso em Engenharia Industrial Química.

AZEVEDO, D.A., LACORTE, S., VIANA, P. and BARCELÓ, D., 2001. Occurrence of nonylphenol and bisphenol-A in surface waters from Portugal. Journal of the Brazilian Chemical Society, vol. 12, no. 4, pp. 532-537. http://dx.doi.org/10.1590/S010350532001000400015 .

BERALDO, D.A.S., 2012. Desenvolvimento e validação de método análitico para análise de bisfenol A e nonifenol em águas superficiais da cidade de Americana, SP. São Paulo: Universidade de São Paulo. Dissertação de Mestrado.

BESERRA, M.R., SCHIAVINI, J.A., RODRIGUES, W.C. and PEREIRA, C.D.S.S., 2012. O bisfenol A: sua utilização e a atual polêmica em relação aos possíveis danos à saúde humana. Revista Eletrônica TECCEN, vol. 5, no. 1, pp. 37-46. http://dx.doi. org/10.21727/teccen.v5i1.108.

BLUME, K.K., MACEDO, J.C., MENEGUZZI, A., SILVA, L.B., QUEVEDO, D.M. and RODRIGUES, M.A., 2010. Water quality assessment of the Sinos River Southern Brazil. Brazilian Journal of Biology $=$ Revista Brasileira de Biologia, vol. 70, no. 4, suppl., pp. 1185-1193. http://dx.doi.org/10.1590/S151969842010000600008. PMid:21225160.

BUENO, M.J., GOMEZ, M.J., HERRERA, S., HERNANDO, M.D., AGÜERA, A. and FERNÁNDEZ-ALBA, A.R., 2012. Occurrence and persistence of organic emerging contaminants and priority pollutants in five sewage treatment plants of Spain: two years pilot survey monitoring. Environmental Pollution, vol. 164, pp. 267-273. http://dx.doi.org/10.1016/j.envpol.2012.01.038. PMid:22387188.

COUSINS, I.T., STAPLES, C.A., KLEĈKA, G.M. and MACKAY, D., 2002. A multimedia assessment of the environmental fate of bisphenol A. Human and Ecological Risk Assessment, vol. 8, no. 5, pp. 1107-1135. http://dx.doi.org/10.1080/1080-700291905846.

CRAIN, D.A., ERIKSEN, M., IGUCHI, T., JOBLING, S., LAUFER, H., LEBLANC, G.A. and GUILLETTE JUNIOR, L.J., 2007. An ecological assessment of bisphenol-A: evidence from comparative biology. Reproductive Toxicology, vol. 24, no. 2, pp. 225-239. http://dx.doi.org/10.1016/j.reprotox.2007.05.008. PMid:17604601.

CZARCZYŃSKA-GOŚLIŃSKA, B., ZGOŁA-GRZESKOWIAK, A., JESZKA-SKOWRON, M., FRANKOWSKI, R. and GRZEŚKOWIAK, T., 2017. Detection of bisphenol A, cumylphenol and parabens in surface waters of Greater Poland Voivodeship. Journal of Environmental Management, vol. 204, no. 1, pp. 50-60. http://dx.doi.org/10.1016/j.jenvman.2017.08.034. PMid:28854378.

DAFOUZ, R., CÁCERES, N., RODRÍGUEZ-GIL, J.L., MASTROIANNI, N., LÓPEZ DE ALDA, M., BARCELÓ, D., MIGUEL, Á.G. and VALCÁRCEL, Y., 2018. Does the presence of caffeine in the marine environment represent an environmental risk? A regional and global study. The Science of the Total Environment, vol. 615, pp. 632-642. http://dx.doi.org/10.1016/j. scitotenv.2017.09.155. PMid:28992490.

DIAMANTI-KANDARAKIS, E., BOURGUIGNON, J.P., GIUDICE, L.C., HAUSER, R., PRINS, G.S., SOTO, A.M., ZOELLER, R.T. and GORE, A.C., 2009. Endocrine-disrupting chemicals: an Endocrine Society scientific statement. Endocrine Reviews, vol. 30, no. 4, pp. 293-342. http://dx.doi.org/10.1210/ er.2009-0002. PMid:19502515.

EUROPEAN COMMUNITY, 2008. European Union up dated risk assessment report: bisphenol A, CAS No: 80-05-7. Luxembourg: Office for Official Publications of the European Communities, Institute for Health and Consumer Protection, European Chemicals Bureau, European Commission Joint Research Centre.

EUROPEAN COMMUNITY, 2010. European Union risk assessment report: 4,4'-isopropylidenediphenol (Bisphenol-A). Luxembourg: European Communities.

EUROPEAN MEDICINES AGENCY PRE-AUTHORISATION EVALUATION OF MEDICINES FOR HUMAN USE - EMEA, 2006 [viewed 14 March 2018]. EMEA/CHMP/SWP/4447/00 [online]. London. Available from: http://www.ema.europa.eu/ docs/en_GB/document_library/Scientific_guideline/ 2009/10/ WC500003978.pdf

FERREIRA, A.P., 2005. Caffeine as an environmental indicator for assessing urban aquatic ecosystems. Cadernos de Saude Publica, vol. 21, no. 6, pp. 1884-1892. http://dx.doi.org/10.1590/ S0102-311X2005000600038. PMid:16410875.

FIGUEIREDO, J.A.S., DRUMM, E., RODRIGUES, M.A. and SPILKI, F.R., 2010. The Rio dos Sinos watershed: an economic and social space and its interface with environmental status. Brazilian Journal of Biology $=$ Revista Brasileira de Biologia, 
vol. 70, no. 4, suppl., pp. 1131-1136. http://dx.doi.org/10.1590/ S1519-69842010000600001. PMid:21225153.

FROEHNER, S., MACHADO, K.S., FALCÃO, F., MONNICH, C. and BESSA, M., 2011. Inputs of domestic and industrial sewage in Upper Iguassu, Brazil identified by emerging compounds. Water, Air, and Soil Pollution, vol. 215, no. 1-4, pp. 251-259. http://dx.doi.org/10.1007/s11270-010-0475-0.

FROMME, H., KÜCHLER, T., OTTO, T., PILZ, K., MÜLLER, J. and WENZEL, A., 2002. Occurrence of phthalates and bisphenol $\mathrm{A}$ and $\mathrm{F}$ in the environment. Water Research, vol. 36, no. 6, pp. 1429-1438. http://dx.doi.org/10.1016/S0043-1354(01)00367-0. PMid:11996333.

FUNDAÇÃO ESTADUAL DE PROTEÇÃO AMBIENTAL HENRIQUE LUIS ROESSLER - FEPAM, 2016 [viewed 7 December 2017]. Qualidade ambiental: região hidrográfica do Guaiba [online]. Porto Alegre. Available from: http://www.fepam. rs.gov.br/qualidade/qualidade_sinos/sinos.asp

FÜRHACKER, M., SCHARF, S. and WEBER, H., 2000. Bisphenol A: emissions from point sources. Chemosphere, vol. 41, no. 5, pp. 751-756. http://dx.doi.org/10.1016/S0045-6535(99)00466-X. PMid:10834378.

GROSHART, C.P., OKKERMAN, P.C. and PIJNENBURG, A.M.C.M., 2001. Chemical study on bisphenol A. The Netherlands: Ministerie van Verkeer en Waterstaat.

GUO, L., LI, Z., GAO, P., HU, H. and GIBSON, M., 2015. Ecological risk assessment of bisphenol A in surface waters of China based on both traditional and reproductive endpoints. Chemosphere, vol. 139, pp. 133-137. http://dx.doi.org/10.1016/j. chemosphere.2015.06.001. PMid:26081577.

HEALTH CANADA, 2008. Health risk assessment of bisphenol A from food packing applications. Ottawa: Bureau of Chemical Safety Food Directorate Health Products and Food Branch.

JIN, H. and ZHU, L., 2016. Occurrence and partitioning of bisphenol analogues in water and sediment from Liaohe River Basin and Taihu Lake, China. Water Research, vol. 103, pp. 343-351. http://dx.doi.org/10.1016/j.watres.2016.07.059. PMid:27486043.

JONKERS, N., SOUSA, A., GALANTE-OLIVEIRA, S., BARROSO, C.M., KOHLER, H.P. and GIGER, W., 2010. Occurrence and sources of selected phenolic endocrine disruptors in Ria de Aveiro, Portugal. Environmental Science and Pollution Research International, vol. 17, no. 4, pp. 834-843. http://dx.doi. org/10.1007/s11356-009-0275-5. PMid:20017000.

KANG, J. and KONDO, F., 2002. Bisphenol A degradation by bacteria isolated from river water. Archives of Environmental Contamination and Toxicology, vol. 43, no. 3, pp. 265-269. http://dx.doi.org/10.1007/s00244-002-1209-0. PMid:12202920.

KANG, J.-H., AASI, D. and KATAYAMA, Y., 2007. Bisphenol $A$ in the aquatic environment and its endocrine-disruptive effects on aquatic organisms. Critical Reviews in Toxicology, vol. 37, no. 7, pp. 607-625. http://dx.doi.org/10.1080/10408440701493103. PMid:17674214.

KLEČKA, G.M., STAPLES, C., CLARK, K.E., VAN DER HOEVEN, N., THOMAS, D.E. and HENTGES, S.G., 2009. Exposure analysis of bisphenol a in surface water systems in North America and Europe. Environmental Science \& Technology, vol. 43, no. 16, pp. 6145-6150. http://dx.doi.org/10.1021/es900598e. PMid:19746705.

KOLPIN, D.W., FURLONG, E., MEYER, M.T., THURMAN, E.M., ZAUGG, S.D., BARBER, L.B. and BUXTON, H.T.,
2002. Pharmaceuticals, hormones, and other organic wastewater contaminants in U.S. streams, 1999-2000: a national reconnaissance. Environmental Science \& Technology, vol. 36, no. 6, pp. 12021211. http://dx.doi.org/10.1021/es011055j. PMid:11944670.

KOMORI, K., SUZUKI, Y., MINAMIYAMA, M. and HARADA, A., 2013. Occurrence of selected pharmaceuticals in river water in Japan and assessment of their environmental risk. Environmental Monitoring and Assessment, vol. 185, no. 6, pp. 4529-4536. http://dx.doi.org/10.1007/s10661-012-2886-4. PMid:23054265.

KURISSERY, S., KANAVILLIL, N., VERENITCH, S. and MAZUMDER, A., 2012. Caffeine as an anthropogenic marker of domestic waste: a study from Lake Simcoe watershed. Ecological Indicators, vol. 23, pp. 501-508. http://dx.doi.org/10.1016/j. ecolind.2012.05.001.

LINDEN, R., ANTUNES, M.V., HEINZELMANN, L.S., FLECK, J.D., STAGGEMEIER, R., FABRES, R.B., VECCHIA, A.D., NASCIMENTO, C.A. and SPILKI, F.R., 2015. Caffeine as an indicator of human fecal contamination in the Sinos River: a preliminary study. Brazilian Journal of Biology $=$ Revista Brasileira de Biologia, vol. 75, no. 2, suppl., pp. 81-84. http:// dx.doi.org/10.1590/1519-6984.0513. PMid:26270218.

LIU, D., LIU, J., GUO, M., XU, H., ZHANG, S., SHI, L. and YAO, C., 2016. Occurrence, distribution, and risk assessment of alkylphenols, bisphenol A, and tetrabromobisphenol A in surface water, suspended particulate matter, and sediment in Taihu Lake and its tributaries. Marine Pollution Bulletin, vol. 112, no. 1-2, pp. 142-150. http://dx.doi.org/10.1016/j.marpolbul.2016.08.026. PMid:27539633.

MEESTERS, R.J. and SCHRÖDER, H.F., 2002. Simultaneous determination of 4-nonylphenol and bisphenol A in sewage sludge. Analytical Chemistry, vol. 74, no. 14, pp. 3566-3574. http://dx.doi. org/10.1021/ac011258q. PMid:12139069.

MOHAPATRA, D.P., BRAR, S.K., TYAGI, R.D. and SURAMPALLI, R.Y., 2010. Physio-chemcial pretreatment and biotransformation of wastewater and wastewater sludge-fate of bisphenol A. Chemosphere, vol. 78, no. 8, pp. 923-941. http:// dx.doi.org/10.1016/j.chemosphere.2009.12.053. PMid:20083294.

MONTAGNER, C.C., UMBUZEIRO, G.A., PASQUINI, C. and JARDIM, W.F., 2014. Caffeine as an indicator of estrogenic activity in source water. Environmental Science. Processes \& Impacts, vol. 16, no. 8, pp. 1866-1869. http://dx.doi.org/10.1039/ C4EM00058G. PMid:24939322.

MOREIRA, M., AQUINO, S., COUTRIM, M., SILVA, J. and AFONSO, R., 2011. Determination of endocrine-disrupting compounds in waters from Rio das Velhas, Brazil, by liquid chromatography/high resolution mass spectrometry (ESI-LCIT-TOF/MS). Journal Environmental Technology, vol. 32, no. 12, pp. 1409-1417. http://dx.doi.org/10.1080/09593330.2010.5 37829. PMid:21970183.

MOREIRA, M.A., 2010. Avaliação de perturbadores endócrinos em àgua do Rio das Velhas por cromatografia líquida acoplada à espectrometria de massas. Ouro Preto: Universidade Federal de Ouro Preto. Dissertação de Mestrado.

NASCIMENTO, C.A. and NAIME, R., 2009. Monitoramento físico-químico das águas do arroio Pampa em Novo Hamburgo (RS). Estudos Tecnológicos, vol. 5, no. 2, pp. 245-269. http:// dx.doi.org/10.4013/ete.2009.52.10

PAÍGA, P. and DELERUE-MATOS, C., 2017. Anthropogenic contamination of Portuguese coastal waters during the bathing season: Assessment using caffeine as a chemical marker. Marine 
Pollution Bulletin, vol. 120, no. 1-2, pp. 355-363. http://dx.doi. org/10.1016/j.marpolbul.2017.05.030. PMid:28526198.

PEELER, K.A., OPSAHL, S.P. and CHANTON, J.P., 2006. Tracking anthropogenic inputs using caffeine, indicator bacteria, and nutrients in rural freshwater and urban marine systems. Environmental Science \& Technology, vol. 40, no. 24, pp. 76167622. http://dx.doi.org/10.1021/es061213c. PMid:17256503.

RODRIGUES, M.T., HENZEL, A., STAGGEMEIER, R., DE QUEVEDO, D.M., RIGOTTO, C., HEINZELMANN, L., DO NASCIMENTO, C.A. and SPILKI, F.R., 2015. Human adenovirus spread, rainfalls, and the occurrence of gastroenteritis cases in a Brazilian basin. Environmental Monitoring and Assessment, vol. 187, no. 11, pp. 720. http://dx.doi.org/10.1007/s10661-0154917-4. PMid:26514803.

SELVARAJ, K.K., SHANMUGAM, G., SAMPATH, S., LARSSON, D.G. and RAMASWAMY, B.R., 2014. GC-MS Determination of bisphenol A and alkyl phenolethoxylates in river water from India and their ecotoxicological risk assessment. Ecotoxicology and Environmental Safety, vol. 99, pp. 13-20. http://dx.doi. org/10.1016/j.ecoenv.2013.09.006. PMid:24183982.

SPADOTO, M., 2013. Análise dos efeitos tóxicos do nonifenol e bisfenol A em organismos de água doce. São Carlos: Universidade de São Paulo. Dissertação de Mestrado em Ciências da Engenhara Ambiental.

SPENCE, P.L., 2015. Using caffeine as a water quality indicator in the ambient monitoring program for Third Fork Creek Watershed, Durham, North Carolina. Environmental Health Insights, vol. 9, no. 2, suppl. 2, pp. 29-34. PMid:26157335.

STAPLES, C.A., DORN, P.B., KLECKA, G.M., O’BLOCK, S.T., BRANSON, D.R. and HARRIS, L.R., 2000. Bisphenol A concentrations in receiving waters near US manufacturing and processing facilities. Chemosphere, vol. 40, no. 5, pp. 521-525. http://dx.doi.org/10.1016/S0045-6535(99)00288-X. PMid:10665389.

TEEGUARDEN, J.G., CALAFAT, A.M., YE, X., DOERGE, D.R., CHURCHWELL, M.I., GUNAWAN, R. and GRAHAM, M.K., 2011. Twenty-four hour human urine and sérum profiles of bisphenol A during high-dietary exposure. Toxicological Sciences, vol. 123, no. 1, pp. 48-57. http://dx.doi.org/10.1093/ toxsci/kfr160. PMid:21705716.

THE WEATHER COMPANY LLC, 2017 [viewed 7 December 2017]. Available from: https://www.wunderground.com/personalweather-station/dashboard?ID=IRSSOLEO2\#history/tgraphs/ s20171112/e20171112/mdaily
VOM SAAL, F.S., NAGEL, S.C., COE, B.L., ANGLE, B.M. and TAYLOR, J.A., 2012. The estrogenic endocrine disrupting chemical bisphenol A(BPA) and obesity. Molecular and Cellular Endocrinology, vol. 354, no. 1-2, pp. 74-84. http://dx.doi. org/10.1016/j.mce.2012.01.001. PMid:22249005.

WINTGENS, T., GALLENKEMPER, M. and MELIN, T., 2003. Occurrence and removal of endocrine disrupters in landfill leachate treatment plants. Water Science and Technology, vol. 48, no. 3, pp. 127-134. http://dx.doi.org/10.2166/wst.2003.0180. PMid:14518864.

WRIGHT-WALTERS, M., VOLZ, C., TALBOTT, E. and DAVIS, D., 2011. An updated weight of evidence approach to the aquatic hazard assessment of Bisphenol A and the derivation a new predicted no effect concentration (Pnec) using a non-parametric methodology. The Science of the Total Environment, vol. 409, no. 4, pp. 676-685. http://dx.doi.org/10.1016/j.scitotenv.2010.07.092. PMid:21130487.

WU, C., HUANG, X., LIN, J. and LIU, J., 2015. Occurrence and fate of selected endocrine-disrupting chemicals in water and sediment from an urban lake. Archives of Environmental Contamination and Toxicology, vol. 68, no. 2, pp. 225-236. http://dx.doi.org/10.1007/s00244-014-0087-6. PMid:25298153.

YAMAZAKI, E., YAMASHITA, N., TANIYASU, S., LAM, J., LAM, P.K., MOON, H.B., JEONG, Y., KANNAN, P., ACHYUTHAN, H., MUNUSWAMY, N. and KANNAN, K., 2015. Bisphenol A and other bisphenol analogues including BPS and BPF in surface water samples from Japan, China, Korea and India. Ecotoxicology and Environmental Safety, vol. 122, pp. 565-572. http://dx.doi. org/10.1016/j.ecoenv.2015.09.029. PMid:26436777.

ZHAO, J.L., YING, G.G., WANG, L., YANG, J.F., YANG, X.B., YANG, L.H. and LI, X., 2009. Determination of phenolic endocrine disrupting chemicals and acidic pharmaceuticals in surface water of the Pearl Rivers in South China by gas chromatographynegative chemical ionization-mass spectrometry. The Science of the Total Environment, vol. 407, no. 2, pp. 962-974. http:// dx.doi.org/10.1016/j.scitotenv.2008.09.048. PMid:19004474.

ZHAO, J.L., YING, G.G., LIU, Y.S., CHEN, F., YANG, J.F., WANG, L., YANG, X.B., STAUBER, J.L. and WARNE, M.S., 2010. Occurrence and a screening-level risk assessment of human pharmaceuticals in the Pearl River system, South China. Environmental Toxicology and Chemistry, vol. 29, no. 6, pp. 1377-1384. PMid:20821582. 